\title{
Cu and Ni Mop up from Spent Lubrication Oil Using Disposed Plastic Materials
}

\author{
D. T. Kukwa \\ Department of Chemistry, \\ Benue State University \\ Makurdi, Nigeria
}

\author{
R. E. Ikyereve \\ Department of Chemistry, \\ Loughborough University, \\ Loughborough, UK
}

\author{
E.O. Agbo \\ Department of Chemistry, \\ Benue State University \\ Makurdi, Nigeria
}

\begin{abstract}
Spent lubrication oil from a serviceable, functional motor vehicle was cleaned of $\mathrm{Cu}$ and $\mathrm{Ni}$ using five different types of waste plastic materials (plastic water bottles, vegetable oil gallons and engine oil gallons) in batch adsorption processes. Atomic Absorption spectral (AAS) analysis of the spent oil before cleaning showed that Copper $(\mathrm{Cu})$ was present at $18.2 \mathrm{mgL}-1$ and nickel (Ni) at $26.1 \mathrm{mgL}-1$ levels. After treatment with the waste plastics, final product plastic (FPP), Goshen water plastic (GWP), water-first plastic (WFP), engine oil waste plastic gallon (EOG) and vegetable oil waste plastic gallon (VOG), the engine oil was observed to contain reduced levels of $\mathrm{Cu}$ to as low as $2.3,3.2,2.7,2.4$ and $2.9 \mathrm{mgL}-1$ respectively while Ni reduced to 10.6, 11.1, 10.7, 10.1 and $10.3 \mathrm{mgL}-1$ respectively at equilibrium. The Gibbs free energy of adsorption for the plastic bottles and gallons was determined using standard methods and fell in the range of -0.516 and $-4.972 \mathrm{kJmol}-1$, which indicates that the process was exclusively physical adsorption. The modified Arrhenius type equation described the metals adsorption pattern onto the plastic materials.
\end{abstract}

Keywords: Spent lubrication oil, adsorbents, heavy metals, thermodynamic parameters, adsorption, Gibbs free energy, activation energy.

\section{INTRODUCTION}

Environmental pollution is currently one of the issues of concern worldwide. Heavy metals found in engine oils is one of the most worrying pollution sources, as it poses a disposal issue to the environment. The effects of these metals on life could be particularly serious in both plants and animals including man through the bioaccumulation in food chain [1]. Nickel and copper along with mercury and arsenic ions are among the cations of high toxicity for both plants and animals including microorganisms [2-4]. These metals, unfortunately, are found in the environment including water bodies which are a source of drinking water at concentrations beyond their permissible levels. For example, around $1.4 \mathrm{mg} /$ day and 0.05 $\mathrm{mg}$ /day respectively are found in soft and hard water sources when the guideline for maximum acceptable copper concentration in drinking water is less than $300 \mu \mathrm{g} / \mathrm{dm} 3$ [5-7]. These metals could be traced to sources like waste-oils and other industrial wastes in the form of leachates from landfills [8-10] among other sources. Removal of these metals from solution is usually achieved using methods such as; precipitations, ion exchange, adsorption, reverse osmosis, electrodialysis, solvent extraction etc. [11-13]. Adsorption is one of the most preferred methods since it is cheaper, economical and presents little or no disposal issues. A number of investigations have been focused on the use of low-cost adsorbents in order to minimize processing costs for wastewater treatment [14-19]. Low-cost adsorbents, like waste ashes and PET, agricultural wastes, waste cobs and husks, activated carbon, chitosan and zeolites have been explored in recent years and shown to be effective at removing metal ions from wastewaters and oils $[14,16,18$ 22]. A more recent investigation showed that waste-plastic materials can be used as adsorbents for the removal of $\mathrm{Cr}$ and $\mathrm{Pb}$ from spent engine oil [23]. The present paper however, seeks to investigate the efficacy of the waste plastics in the removal of $\mathrm{Ni}$ and $\mathrm{Cu}$ from waste engine oil.

\section{MATERIALS AND METHODS 2.1 Materials}

Five waste-plastic samples namely; water-first plastic (WFP*), final product plastic (FPP**), Goshen-water plastic
$(\mathrm{GWP} * * *)$, vegetable oil gallon (VOG****) and engine oil gallon $\left(\mathrm{EOG}^{* * * * *)}\right.$ were collected from waste bins while the spent engine oil was obtained from a marked four-cylinder vehicle after covering a distance of about 1350 kilometers from an automobile workshop in Makurdi town, Nigeria. The labels on the waste-plastic materials were removed and the plastics were cut, thoroughly washed with water and air-dried. They were shredded into smaller sizes, pounded into chips, sieved with a $2 \mathrm{~mm}$ sieve to obtain a powder with good and uniform particle distribution and stored in polyethene bags for subsequent analyses and application.

\subsection{Physicochemical characterization of the adsorbents}

The adsorbents $\mathrm{pH}$, bulk density and porosity were determined as described by Itodo and coworkers [17]. The adsorbent $\mathrm{pH}$ was determined by adding $1.0 \mathrm{~g}$ of the sample into $100 \mathrm{~mL}$ of distilled water and stirred for $1 \mathrm{~h}$ at regular interval. The mixture was then filtered and the $\mathrm{pH}$ of the filtrate was determined using $\mathrm{pH}$ meter. The bulk density expressed in $\mathrm{g} / \mathrm{mL}$ was determined using the tapping method. The adsorbent porosity was determined using the saturation method by adding $3.0 \mathrm{~g}$ of sample into $100 \mathrm{~mL}$ distilled water and allowed to stand for $48 \mathrm{~h}$. The mixture was then filtered and the filtrate volume measured. The iodine adsorption ratio (IAR) was determined as described by Malik and coworkers [24]. Portions of the adsorbent $(1.0 \mathrm{~g})$ were slurred in excess $(25 \mathrm{~mL}, 0.05 \mathrm{M})$ iodine solution in a beaker. The mixture was then stirred vigorously for $10 \mathrm{~min}$ and filtered through a funnel impregnated with glass wool. $20 \mathrm{~mL}$ of the filtrate was back-titrated with $0.1 \mathrm{M}$ sodium thiosulphate solution. The iodine ratio was calculated as moles of iodine adsorbed per gram of adsorbent. The adsorbent attrition factor (AF) was determined using the procedure described earlier [25], which is based on the measurement of the percentage of the adsorbent retained in a $2 \mathrm{~mm}$ sieve after $1.0 \mathrm{~g}$ was stirred with magnetic stirrer in $100 \mathrm{~mL}$ acetate buffer of $\mathrm{pH} 4.0$ for $4 \mathrm{~h}$, which was calculated based on the weight loss of the adsorbent after the stirring and reported as percentage attrition. Cation exchange capacity (CEC) was obtained 
according to the method described by Kandah [26]. The Adsorbent $(2.0 \mathrm{~g})$ was left for $4 \mathrm{~h}$ in an excess of $33 \mathrm{~mL}$ of 1.0 $M$ sodium acetate solution after which it was filtered and washed with $33 \mathrm{~mL}$ isopropyl alcohol. The procedure was repeated thrice but without washing with the alcohol at the last round. Thereafter, the filtered adsorbent was washed with $33 \mathrm{~mL}$ of $1.0 \mathrm{M}$ ammonium acetate solution and the concentration of the displaced $\mathrm{Na}$ in the filtrate determined using a Jenway flame photometer model PFP 7.

$* ; * * ; * * *=$ water first $(\mathrm{WF})$, final product $(\mathrm{FP})$, Goshen water $(\mathrm{GW})$ : Company name of water supplies

$* * * * ; * * * * *=$ vegetable oil gallon $(\mathrm{VOG})$ and engine oil gallon (EOG): Type of oil plastic

\subsection{Adsorption Studies}

The method by Jabar and coworkers [27] was adopted in which the initial concentrations of $\mathrm{Cu}$ and $\mathrm{Ni}$ in the spent lubrication oil were determined by measuring $100 \mathrm{~mL}$ of untreated spent lubrication oil into five different beakers; the first beaker was kept at room temperature of $305 \mathrm{~K}$ while the rest (one at a time) had their temperatures raised to 315,325 , 335 , and $345 \mathrm{~K}$ respectively in a warm water bath. A one in ten dilution of the oil with kerosene was done in a labeled specimen bottle in preparation for AAS analysis. The same procedure was carried out for $100 \mathrm{~mL}$ of the spent lubrication oil after treatment with $5.0 \mathrm{~g}$ of the adsorbent and stirred for $30 \mathrm{~min}$ (while the temperature was being raised) and filtered. The equilibrium concentrations of the metals were then determined using a Buck Scientific Atomic Absorption Spectrophotometer model VGP 210.

\subsection{Adsorption Thermodynamics}

The thermodynamic properties of the adsorbents were determined using the Van't Hoff's equation (Venkatraman and coworkers) [22] as expressed in equation (1).

$$
\begin{aligned}
\ln K_{a d} & =-\frac{\Delta H^{\circ}}{R T}+\frac{\Delta s^{\circ}}{R} \\
K_{a d} & =\frac{c_{a d}}{c_{a}} \\
\Delta G^{\circ} & =-R T \ln K_{a d}
\end{aligned}
$$

Where;

$\Delta \mathrm{H}^{\mathrm{o}}$ is enthalpy $\left(\mathrm{kJmol}^{-1}\right), \Delta \mathrm{S}^{\mathrm{o}}$ is entropy $\left(\mathrm{Jmol}^{-1} \mathrm{~K}^{-1}\right), \Delta \mathrm{G}^{\mathrm{o}}$ is Gibb's free energy $\left(\mathrm{kJmol}^{-1}\right), \mathrm{R}$ is the gas constant $(8.314$ $\mathrm{Jmol}^{-1} \mathrm{~K}^{-1}$ ), $\mathrm{T}$ is temperature in Kelvin, $\mathrm{K}_{\mathrm{ad}}$ is the adsorption equilibrium constant, $\mathrm{C}_{\mathrm{ad}}$ is the amount of metal adsorbed onto the adsorbent per litre of the analyte solution at equilibrium in $\mathrm{mLL}^{-1}$ and $\mathrm{C}_{\mathrm{e}}$ is the equilibrium concentration $\left(\mathrm{mgL}^{-1}\right)$ of metal left unadsorbed in the analyte solution.

\section{RESULTS AND DISCUSSION}

\subsection{Physicochemical characterization of the adsorbents}

Results for Physicochemical Characterization of the adsorbents (FPP, WFP, GWP, EOG and VOG) are shown in Table 1.

The $\mathrm{pH}$ of adsorbents influences the species and extent of adsorption. VOG has the highest $\mathrm{pH}$ value of 7.78 followed by EOG with $\mathrm{pH}$ of 7.53 , GWP with $\mathrm{pH} 7.28$, WFP with $\mathrm{pH}$ 6.80 and FPP with $\mathrm{pH}$ 6.71. Three of the adsorbents, VOG,
EOG and GWP each had a slightly alkaline $\mathrm{pH}$ value while the rest two, WFP and FPP had slightly acidic $\mathrm{pH}$ values.

The bulk density (BD) of adsorbents indicates the mass of the adsorbent that can be contained in a filter of a given capacity during the design of an adsorption column and the quantity of the treated liquid retained. The bulk density of the adsorbents increases in the order $\mathrm{EOG}<\mathrm{VOG}<\mathrm{WFP}<\mathrm{FPP}<\mathrm{GWP}$ with values $0.1702 \mathrm{~g} / \mathrm{mL}, 0.1951 \mathrm{~g} / \mathrm{mL}, 0.3200 \mathrm{~g} / \mathrm{mL}, 0.3478 \mathrm{~g} / \mathrm{mL}$ and $0.4211 \mathrm{~g} / \mathrm{mL}$ respectively as shown in Table 1 . Porosity indicates the efficiency of an adsorbent during adsorption process. The porosity of the adsorbents decreases in the order EOG >VOG > FPP >WFP > GWP with values $12 \mathrm{~mL}, 10$ $\mathrm{mL}, 9.5 \mathrm{~mL}, 9 \mathrm{~mL}$ and $8 \mathrm{~mL}$ respectively.

Iodine adsorption ratio (IAR) also measures the adsorptive performance of an adsorbent. These plastic adsorbents show increase in IAR in the order WFP $<$ GWP $<$ FPP $<$ VOG $<$ EOG with values $0.0205,0.0455,0.0550,0.0890$ and $0.0915 \mathrm{~mol} / \mathrm{g}$ respectively. Attrition factor (AF) is the measure of the resistance of an adsorbent to mechanical abrasion and indicates the mechanical strength of that adsorbent during transportation, handling and regeneration. The $\mathrm{AF}$ of the adsorbents increases in the order EOG $<$ VOG $<$ FPP $<$ WFP $<$ GWP with values $1,3,8,11$ and $17 \%$ respectively. Cation exchange capacity (CEC) measures the quantity of adsorptive sites the adsorbent possesses. The CEC of the adsorbents under investigation increases in the order GWP $<$ WFP $<$ FPP $<$ VOG < EOG with values $2.50,3.50,3.75,6.25$ and 7.50 $\mathrm{mg} / \mathrm{L}$ respectively.

\subsection{Adsorption Studies}

The adsorption of the metals by the adsorbents at equilibrium is shown in Table 2. From the generated data,

VOG with a slightly alkaline $\mathrm{pH}$ of 7.78 has $\mathrm{Ni}$ metal preferentially adsorbed at all the experimental temperatures than $\mathrm{Cu}$ although the amount adsorbed decreases as the temperature increases from $305 \mathrm{~K}$ to $345 \mathrm{~K}$. The trend of adsorption was thus; $\mathrm{Ni}\left(15.8 \mathrm{mgL}^{-1}\right)>\mathrm{Cu}\left(15.3 \mathrm{mgL}^{-1}\right)$. At the $\mathrm{pH}$ of 7.53, the adsorption for EOG was such that $\mathrm{Ni}$ (16.0 $\left.\mathrm{mgL}^{-1}\right)>\mathrm{Cu}\left(15.3 \mathrm{mgL}^{-1}\right)$. For GWP with the $\mathrm{pH}$ of 7.28 , both $\mathrm{Cu}$ and $\mathrm{Ni}$ were adsorbed equally $\left(15.0 \mathrm{mgL}^{-1}\right)$ but as the temperature increased, more $\mathrm{Cu}$ was adsorbed than $\mathrm{Ni}$. At the $\mathrm{pH}$ of 6.80 and $305 \mathrm{~K}$ temperature, WFP favours the adsorption of $\mathrm{Cu}\left(15.5 \mathrm{mgL}^{-1}\right)>\mathrm{Ni}\left(15.4 \mathrm{mgL}^{-1}\right)$. FPP with the $\mathrm{pH}$ of 6.71 and at $305 \mathrm{~K}$ adsorbed $\mathrm{Cu}\left(15.9 \mathrm{mgL}^{-1}\right)>\mathrm{Ni}(15.5$ $\left.\mathrm{mgL}^{-1}\right)$. It was observed that the adsorption was most favoured at neutral $\mathrm{pH}$.

The bulk density of the adsorbents increases in the order EOG $<$ VOG $<$ WFP $<$ FPP $<$ GWP while the amount of metal species adsorbed decreased in somewhat the same order. The general observation could be explained based on the difference in bulk densities of the various adsorbents, the higher the bulk density of the adsorbent, the lower the pore size volume, hence the adsorption of metal ions will be reduced. The adsorption capacity of the adsorbents decreases as their porosity values decreases in the order EOG $<$ VOG $<$ FPP < WFP < GWP. The porosity as well as the CEC also explains the observed behavior of the adsorbents. The porosity of adsorbents plays an important role in the adsorption of metal ions. Adsorbents with high porosity have high adsorption capacity. The porosity and CEC of the adsorbents were observed to decrease in the order EOG $>$ VOG $>$ WFP $>$ FPP $>$ GWP.

The adsorptive performance of the adsorbents decreases as their IAR decreases in the order EOG $>$ VOG $>$ FPP $>$ GWP 
$>$ WFP except that GWP with a little higher IAR value of $0.0455 \mathrm{~mol} / \mathrm{g}$ adsorbed lesser amount of metals than WFP with lower IAR value of $0.0205 \mathrm{~mol} / \mathrm{g}$.

The adsorbents increase in attrition factor $(\mathrm{AF})$ values in the order EOG < VOG < FPP < WFP < GWP but decrease in adsorption performance in the same order implying that an increase in the AF leads to low adsorption capacity or vice versa. The adsorption capacity of the adsorbents decreases in the order EOG $>$ VOG $>$ FPP $>$ WFP $>$ GWP as the effect of CEC follows the same order.

\subsection{Adsorption Thermodynamics}

Using equation (1), the plots of $\ln \mathrm{K}_{\mathrm{ad}}$ against $1 / \mathrm{T}$ for each of the metals, gave straight lines with a slope equal to $\left(\Delta \mathrm{H}^{\circ}\right) / \mathrm{R}$ and intercepts equal to $\left(\Delta \mathrm{S}^{\mathrm{o}}\right) / \mathrm{R}$. $\mathrm{K}_{\mathrm{ad}}$ and $\Delta \mathrm{G}^{\mathrm{o}}$ were calculated from equations 2 and 3 . The values of $K_{a d}$ are presented in Table 2 while those of $\Delta \mathrm{H}^{\mathrm{o}}, \Delta \mathrm{S}^{\mathrm{o}}$ and $\Delta \mathrm{G}^{\mathrm{o}}$ are presented in Table 3. The plots of $\ln K_{a d}$ vs $T$ in figures 1 and 2 show the dependence of equilibrium constants on temperature. The negative slopes of these plots show that metals uptake by these plastic adsorbents is exothermic in nature [28]. The Van't Hoff plots for $\mathrm{Cu}$ adsorption are as presented in figure 3 while those for $\mathrm{Ni}$ adsorption are presented in figure 4 . The values of $\Delta \mathrm{H}^{\mathrm{o}}$ for the adsorption of the metals onto all the adsorbents were negative and in the range of -2.203 to -5.316 $\mathrm{kJmol}^{-1}$. These negative values confirm the exothermic nature of the adsorption process. The positive value of $\Delta \mathrm{S}^{\circ}(0.988$ $\mathrm{Jmol}^{-1} \mathrm{~K}^{-1}$ ) for the adsorption of $\mathrm{Cu}$ by FPP indicates that though there are electrostatic attractions, the metal is still mobile and is loosely adsorbed onto the adsorbent surface during the process. The value of $\Delta \mathrm{S}^{\mathrm{o}}$ for the metals adsorbed onto all other adsorbents is negative indicative of decrease disorder and randomness at the adsorbent-analyte interface. The values of $\Delta \mathrm{G}^{\mathrm{O}}$ for the metals were negative at all the temperatures considered. The negative values of $\Delta \mathrm{G}^{\mathrm{o}}$ show the spontaneous nature of adsorption of the metals onto the adsorbents. $\Delta \mathrm{G}^{\mathrm{o}}$ values which are less than or more negative than $-20.0 \mathrm{kJmol}^{-1}$ are consistent with electrostatic interactions between the adsorption sites and the metal showing physical adsorption while $\Delta \mathrm{G}^{\mathrm{o}}$ values more negative than $-40.0 \mathrm{kJmol}^{-1}$ involve charge sharing or transfer from the adsorbent surface to the metal ion to form a coordinate bond, indicating chemical adsorption [29]. The $\Delta \mathrm{G}^{\mathrm{o}}$ values obtained in this study for the metals are less than $-4.972 \mathrm{kJmol}^{-1}$, indicating that adsorption occurred by physical process.

To further strengthen the asserted adsorption mechanism, activation energy, Ea, and sticking probability, $\mathrm{S}^{*}$, were estimated from the experimental data. They were calculated using a modified Arrhenius equation (equation 4) related to surface coverage of adsorbed species $(\theta)$ [30].

$$
\begin{aligned}
& \mathrm{S}^{*}=(1-\theta) \exp -(\mathrm{Ea} / \mathrm{RT}) \\
& \theta=\left(1-\mathrm{C}_{\mathrm{e}} / \mathrm{C}_{\mathrm{o}}\right)
\end{aligned}
$$

Equation (4) is rearranged as in equation (6).

$\ln (1-\theta)=\ln S^{*}+(\mathrm{Ea} / \mathrm{RT})$

\section{TABLES AND FIGURES/CAPTIONS}

Table 1: Physicochemical Properties of the Plastic Adsorbents

\begin{tabular}{llllll}
\hline Property & FPP & WFP & GWP & EOG & VOG \\
\hline $\mathrm{pH}$ & 6.71 & 6.80 & 7.28 & 7.53 & 7.78 \\
Bulk density $(\mathrm{g} / \mathrm{mL})$ & 0.3478 & 0.3200 & 0.4211 & 0.1702 & 0.1951 \\
Porosity $(\mathrm{mL})$ & 9.5 & 9.0 & 8.0 & 12.0 & 10.0 \\
IAR $(\mathrm{mol} / \mathrm{g})$ & 0.0550 & 0.0205 & 0.0455 & 0.0915 & 0.0890 \\
$\mathrm{AF}(\%)$ & 8.0 & 11.0 & 17.0 & 1.0 & 3.0 \\
$\mathrm{CEC}(\mathrm{mg} / \mathrm{L})$ & 3.75 & 3.50 & 2.50 & 7.50 & 6.25 \\
\hline
\end{tabular}


Table 2: Adsorption of $\mathrm{Cu}$ and $\mathrm{Ni}$ onto Plastic Adsorbents

\begin{tabular}{|c|c|c|c|c|c|c|c|}
\hline \multirow{2}{*}{ Adsorbent } & \multirow{2}{*}{$\mathrm{T}(\mathrm{K})$} & \multicolumn{2}{|l|}{$\mathrm{Cu}$} & \multicolumn{3}{|c|}{$\mathrm{Ni}$} & \multirow[b]{2}{*}{$\mathrm{K}_{\mathrm{ad}}(\mathrm{Ni})$} \\
\hline & & $\begin{array}{c}\mathrm{C}_{\mathrm{o}} \\
(\mathrm{mg} / \mathrm{L})\end{array}$ & $\begin{array}{c}\mathrm{C}_{\mathrm{e}} \\
(\mathrm{mg} / \mathrm{L})\end{array}$ & $\mathrm{K}_{\mathrm{ad}}(\mathrm{Cu})$ & $\begin{array}{l}\mathrm{C}_{\mathrm{o}} \\
(\mathrm{mg} / \mathrm{L})\end{array}$ & $\begin{array}{l}\mathrm{C}_{\mathrm{e}} \\
(\mathrm{mg} / \mathrm{L})\end{array}$ & \\
\hline \multirow[t]{5}{*}{ VOG } & 305 & 18.2 & 2.9 & 5.2759 & 26.1 & 10.3 & 1.5340 \\
\hline & 315 & 18.3 & 3.1 & 4.9032 & 26.2 & 10.5 & 1.4952 \\
\hline & 325 & 18.3 & 3.2 & 4.7188 & 26.3 & 10.7 & 1.4579 \\
\hline & 335 & 18.4 & 3.4 & 4.4118 & 26.4 & 10.9 & 1.4220 \\
\hline & 345 & 18.4 & 3.5 & 4.2571 & 26.6 & 11.2 & 1.3750 \\
\hline \multirow[t]{5}{*}{ WFP } & 305 & 18.2 & 2.7 & 5.7407 & 26.1 & 10.7 & 1.4393 \\
\hline & 315 & 18.3 & 2.9 & 5.3103 & 26.2 & 10.9 & 1.4037 \\
\hline & 325 & 18.3 & 3.0 & 5.1000 & 26.3 & 11.1 & 1.3694 \\
\hline & 335 & 18.4 & 3.2 & 4.7500 & 26.4 & 11.3 & 1.3363 \\
\hline & 345 & 18.4 & 3.3 & 4.5758 & 26.6 & 11.6 & 1.2931 \\
\hline \multirow[t]{5}{*}{ FPP } & 305 & 18.2 & 2.3 & 6.9130 & 26.1 & 10.6 & 1.4623 \\
\hline & 315 & 18.3 & 2.4 & 6.6250 & 26.2 & 10.8 & 1.4259 \\
\hline & 325 & 18.3 & 2.5 & 6.3200 & 26.3 & 11.0 & 1.3909 \\
\hline & 335 & 18.4 & 2.7 & 5.8148 & 26.4 & 11.2 & 1.3571 \\
\hline & 345 & 18.4 & 2.8 & 5.5714 & 26.6 & 11.5 & 1.3130 \\
\hline \multirow[t]{5}{*}{ GWP } & 305 & 18.2 & 3.2 & 4.6875 & 26.1 & 11.1 & 1.3514 \\
\hline & 315 & 18.3 & 3.4 & 4.3824 & 26.2 & 11.4 & 1.2982 \\
\hline & 325 & 18.3 & 3.5 & 4.2286 & 26.3 & 11.6 & 1.2672 \\
\hline & 335 & 18.4 & 3.7 & 3.9730 & 26.4 & 11.9 & 1.2185 \\
\hline & 345 & 18.4 & 3.8 & 3.8421 & 26.6 & 12.1 & 1.1983 \\
\hline \multirow[t]{5}{*}{ EOG } & 305 & 18.2 & 2.4 & 6.5833 & 26.1 & 10.1 & 1.5842 \\
\hline & 315 & 18.3 & 2.6 & 6.0385 & 26.2 & 10.3 & 1.5437 \\
\hline & 325 & 18.3 & 2.7 & 5.7778 & 26.3 & 10.5 & 1.5048 \\
\hline & 335 & 18.4 & 2.9 & 5.3448 & 26.4 & 10.7 & 1.4673 \\
\hline & 345 & 18.4 & 3.0 & 5.1333 & 26.6 & 11.0 & 1.4182 \\
\hline
\end{tabular}


Table 3 Thermodynamic Parameters for the Adsorption of $\mathrm{Cu}$ and $\mathrm{Ni}$ onto Various Plastic Adsorbents

\begin{tabular}{|c|c|c|c|c|c|c|c|c|}
\hline \multirow[b]{2}{*}{ Metal } & \multirow[b]{2}{*}{ Adsorbent } & \multirow{2}{*}{$\begin{array}{c}-\Delta \mathrm{H}^{\mathrm{o}} \\
(\mathrm{kJ} / \mathrm{mol})\end{array}$} & \multirow{2}{*}{$\begin{array}{c}\Delta \mathrm{S}^{\mathrm{o}} \\
(\mathrm{J} / \mathrm{mol} / \mathrm{K})\end{array}$} & \multicolumn{5}{|c|}{$-\Delta \mathrm{G}^{\mathrm{o}}(\mathrm{kJ} / \mathrm{mol})$} \\
\hline & & & & $305 \mathrm{~K}$ & $315 \mathrm{~K}$ & $325 \mathrm{~K}$ & $335 \mathrm{~K}$ & $345 \mathrm{~K}$ \\
\hline \multirow[t]{5}{*}{$\mathrm{Cu}$} & VOG & 4.510 & -0.935 & 4.209 & 4.164 & 4.188 & 4.122 & 4.159 \\
\hline & WFP & 4.504 & -0.416 & 4.438 & 4.374 & 4.404 & 4.345 & 4.360 \\
\hline & FPP & 4.610 & 0.988 & 4.894 & 4.950 & 4.972 & 4.902 & 4.934 \\
\hline & GWP & 4.483 & -2.079 & 3.905 & 3.876 & 3.891 & 3.844 & 3.872 \\
\hline & EOG & 4.612 & 0.312 & 4.767 & 4.714 & 4.729 & 4.679 & 4.704 \\
\hline \multirow[t]{5}{*}{$\mathrm{Ni}$} & VOG & 2.156 & -3.492 & 1.090 & 1.048 & 1.027 & 0.975 & 0.918 \\
\hline & WFP & 2.140 & -4.053 & 0.913 & 0.890 & 0.838 & 0.808 & 0.746 \\
\hline & FPP & 2.113 & -3.741 & 0.964 & 0.917 & 0.892 & 0.863 & 0.774 \\
\hline & GWP & 2.184 & -4.781 & 0.761 & 0.681 & 0.648 & 0.557 & 0.516 \\
\hline & EOG & 2.079 & -3.076 & 1.166 & 1.126 & 1.108 & 1.058 & 1.004 \\
\hline
\end{tabular}

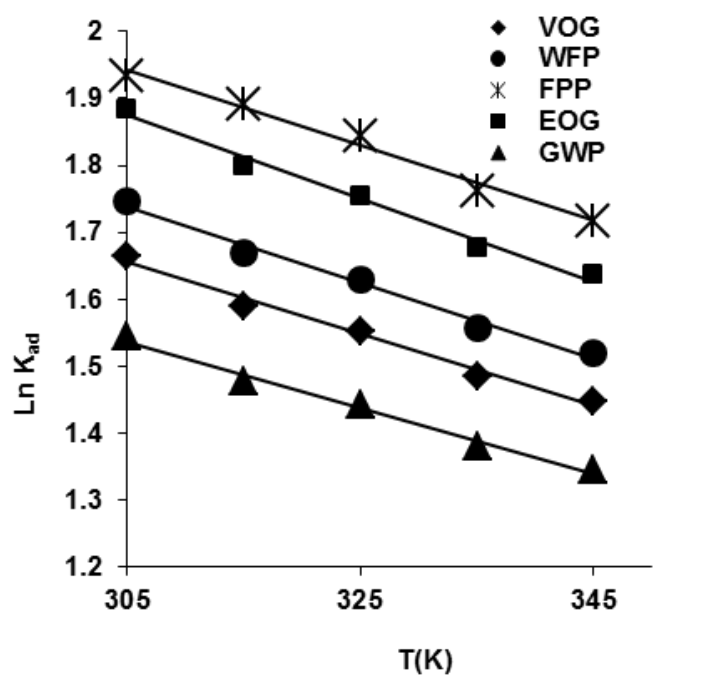

Figure 1 Variation of $\ln K_{a d}$ with $T$ for $C u$ adsorption

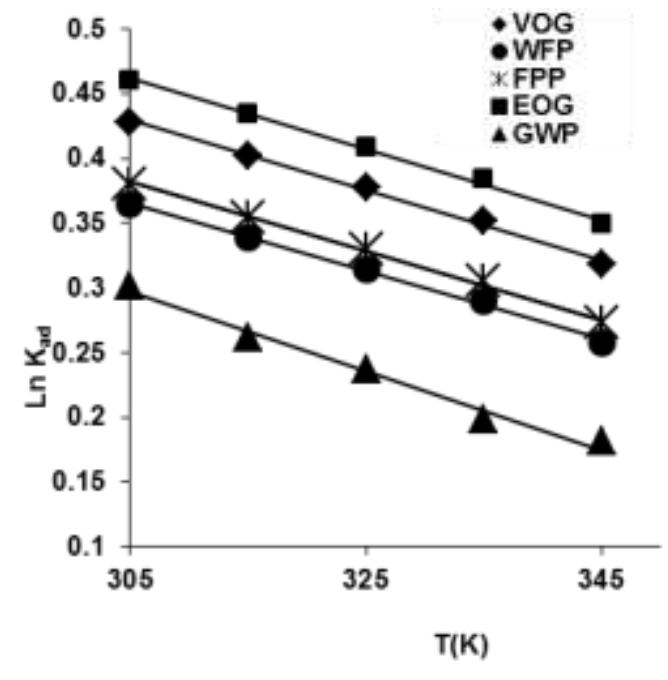

Figure 2 Variation of $I n K_{\text {od }}$ with $T$ for $\mathrm{Ni}$ adsorption 


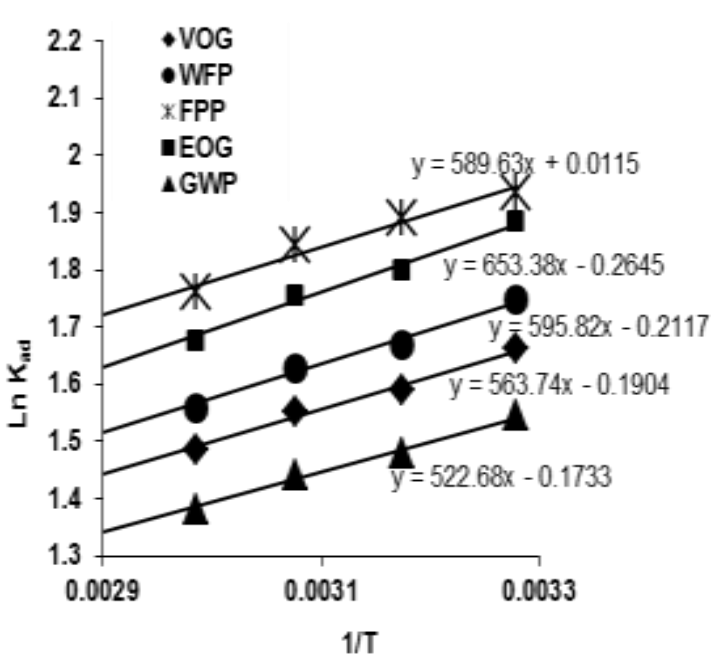

Figure 3 Plots of $\ln K_{\text {od }}$ vs $1 / T$ for Cu adsorption

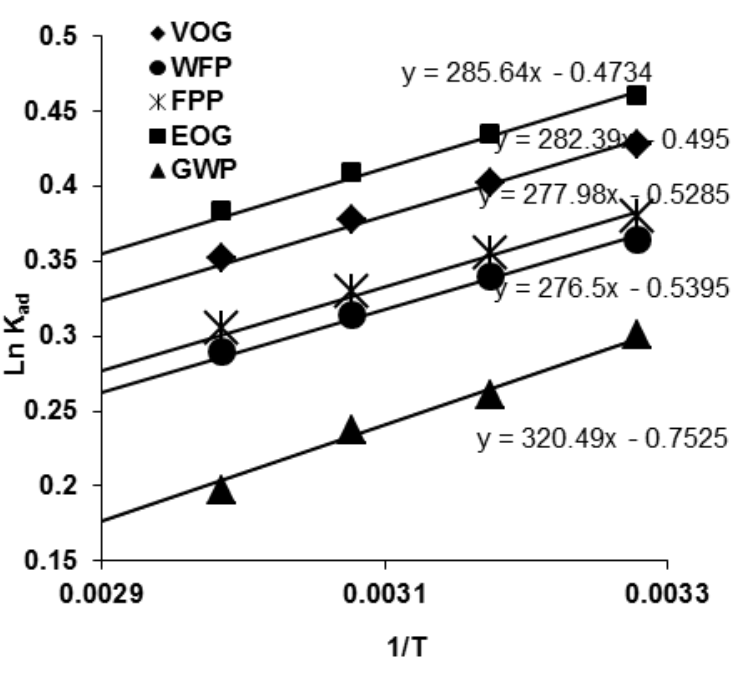

Figure 4 Plots of $\ln K_{a d}$ vs $1 / T$ for Ni adsorption

\section{CONCLUSIONS}

Waste plastic materials can be used effectively as adsorbents for mopping up heavy metal pollutants like $\mathrm{Cu}$ and $\mathrm{Ni}$ from used lubrication oils and other related sources. Plastic gallons used for engine oil storage and transportation (EOG) proved very effective for removing such metals from such sources. This is followed closely by other plastic materials investigated in this work in the order of VOG > FPP > WFP > GWP. Physical adsorption mechanism prevailed in the mopping process, signifying dominance of electrostatic attractions. For all the materials, the adsorption capacity decreased as the temperature was raised and it increases when the pore size in increased. The neutral $\mathrm{pH}$ of the adsorbents used in the study was shown to favor the heavy metal adsorption. The negative low values of $\Delta \mathrm{G}^{\mathrm{o}}$ indicate that the process was driven by electrostatic attractions onto the surface of adsorbent material physical adsorption.

\section{ACKNOWLEDGMENTS}

The authors of this work would like to acknowledge the Benue State University Makurdi, Nigeria particularly the Chemistry department for their support during the course of this work.

\section{REFERENCES}

[1] Para, J. B., Ania, C. O., Arenillas, A., Rubiera, F., Palacios J. M., and Pis, J. J. (2004). Textural Development and Hydrogen Adsorption of Carbon Materials from PET waste. Journal of Alloys and Compounds, 379 (1-2), 280 - 289.

[2] Kabata-Pendias, A., Pendias, H. (1984). Trace Elements in Soils and Plants, CRC Press, Boca Raton.

[3] Train, R.E. (1979) Quality Criteria for Water, Castle House, London.

[4] Bowen, H. J. M. (1979). The Environmental Chemistry of the Elements, Academic Press, London.

[5] Davies, D. J. A., and Bennett, B. G. (1983). Exposure Commitment Assessments of Environmental Pollutants, vol. 3, Monitoring and Assessment Research Centre, London.
[6] Manahan, S.E. (1991). Environmental Chemistry, Lewis, Chelsea, MI, 5th edition.

[7] Murley, L. (1992). Pollution Handbook, National Society for Clean Air and Environmental Protection, Brighton.

[8] Alloway, B. J., Ayres, D.C. (1981). Chemical Principles of Environmental Pollution, Chapman and Hall, Oxford.

[9] Peters, W.C. (1978). Exploration and Mining Geology, Wiley, New York.

[10] O'Neill, P. in: Alloway, B. J. (Ed.), (1990). Heavy Metals in Soils, Blackie and Son, Glasgow.

[11] Griffin R.D. (1988). Principles of Hazardous Materials and Management, Lewis, Ann Arbor.

[12] Davis, M. L and Cornwell, D. A. (1991). Introduction to Environmental Engineering, McGraw-Hill, New York, $2^{\text {nd }}$ edition.

[13] Fergusson, J. E. (1990). The heavy elements: Chemistry, Enviromental impact and Health Effects, Pergamon, Oxford.

[14] Zhan, F. and Itoh, H. (2003). Adsorbents made from Waste Ashes and Post-customer PET and their Potential Utilization in Waste Water Treatment. Journal of Hazardous Materials, 101 (3), 323 - 337.

[15] Kumar, P. S. and Kirthika, K. (2009). Equilibrium and kinetic study of adsorption of nickel from aqueous solution onto bael tree leaf powder. Journal of Engineering Science and Technology, 4 (4), 351 - 361.

[16] Bansal, M., Singh, D., Garg, V. K. and Pawan, R. (2009). Use of Agricultural Waste for the Removal of Ni Ions from Aqueous Solutions: Equilibrium and Kinetic Studies, International Journal of Environmental Science and Engineering, 1 (2), 108 - 114.

[17] Itodo, A.U., Abdulrahman, F.W., Hassan, L.G., Maigandi, S.A., and Itodo, H.U. (2010). Physicochemical parameters of adsorbents from locally sorted $\mathrm{H}_{3} \mathrm{PO}_{4}$ \& $\mathrm{ZnCl}_{2}$ modified agricultural wastes, New York science journal, 3 (5), 17-24.

[18] Demirbas, E., Kobya, M., Senturk E., and Ozkan, T. (2004). Adsorption kinetics for the removal of chromium (VI) from aqueous solutions on the activated carbons prepared from agricultural wastes, Water SA 30(4), 533539. 
[19] Babel, S., Kurniawen, T. A., Hazrel J., and Mater, B. (2003). Maize Cob and Husk as Adsorbents for the removal of $\mathrm{Cd}, \mathrm{Pb}$, and $\mathrm{Zn}$ ions from Waste Water, Journal of Soil Science, 42, 403- 409.

[20] Venkatraman, B.R., Parthasarathy, S., Kasthuri, A., Pandia P., and Arivoli, S. (2009). Adsorption of $\mathrm{Cr}$ ions by Acid Activated Low-cost Carbon-kinetic, thermodynamic and Equilibrium Studies, E- Journal of Chemistry. 6(S1), S1 -S11.

[21] Radnia, H., Ghoreyshi, A. A., and Younesi, H. (2011). Isotherm and kinetics of $\mathrm{Fe}$ (II) adsorption onto chitosan in a batch process, Iranica Journal of Energy \& Environment, 2 (3), 250 - 257.

[22] Ali, S.M.W., Ripin A., and Ahmed, A. (2010). Adsorption of Heavy Metals from Recovered Base Oil using Zeolite, Journal of Applied Sciences, 10 (21), 2688-2692.

[23] Kukwa, D.T., Ikyereve R.E., and Agbo, E.O. (2014). Removal of $\mathrm{Cr}$ and $\mathrm{Pb}$ from spent Engine Oil using Waste Plastic materials as Adsorbent, International Journal of Scientific and Engineering Research, 5 (5), $1162-1169$

[24] Malik, R., Ramteke, D.S., Wate, S.R. (2006). Physicochemical and surface characterization of adsorbent prepared from groundnut shell by $\mathrm{ZnCl}_{2}$ activation and its ability to adsorb colour, Indian journal of chemical Technology, 13, 319-328.

[25] Toles, C.A., Marshall, W. E., Johns, M. M., Wartelle I. A. and McAloon, A. (2000). Acid Activated Carbons from Almond Shells; Physical, Chemical and Adsorptive Properties and Estimated Cost of Production, Bioresource Technology, 71, 87- 92.

[26] Kandah, M.I., Allawzi M.A. and Allabonn, H. (2008). Improvement of Manure Adsorption Capacity for Co Removal by Chemical Treatment with Citric Acids, Jordan Journal of Civil Engineering, 2 (4), 344 - 354.

[27] Jabar, J.M., Mojibola A.A. and Adetuyi, A.O. (2011) Adsorption Thermodynamic Studies of Indigo Adsorption on Some Activated Bio-solids from Dyeing Effluent, Conference Proceedings of the 34th Annual International Conference of Chemical Society of Nigeria.

[28] Smith, J.M., Van Ness, H.C., and Abbott, M.M. (2005) Introduction to Chemival Engineering Thermodynamics, $7^{\text {th }}$ ed. McGraw Hill, New York 492-497

[29] Micheal, H. and Agebaemi, I.S. (2005). Effects of Temperature on the Sorption of $\mathrm{Pb}^{2+}$ and $\mathrm{Cd}^{2+}$ from Aqueous Solution by Caladium bicolor (wild cocoyam) biomass, Electronic Journal of Biotechnology, 8 (2), 163-169.

[30] Chaudhari, A. and Lee, S.L. (2008). Effect of sticking probability on monomer-dimer reaction, Bulletin of the Catalysis Society of India, 7, 90-95. 